\title{
Financial Mobilization Status of People Housing Program - A Case of Rupandehi District of Nepal
}

\author{
Anjay Kumar Mishra*, P. S. Aithal** \& Hamid Saremi*** \\ *Associate Professor, Madan Bhandari Memorial Academy Nepal, Urlabari 3, Morang, Nepal \\ OrcidID: 0000-0003-2803-4918; Email: anjaymishra2000@gmail.com \\ **Professor, College of Management \& Commerce, Srinivas University, Mangalore, India \\ OrcidID: 0000-0002-4691-8736; E-mail: psaithal@gmail.com \\ ***Professor, Industrial Engineering Department, Asar Higher Institute of Education, Masahad- \\ Iran, Email; hadi_sarem@yahoo.com
}

Area of the Paper: Business Management.

Type of the Paper: Research Case Study.

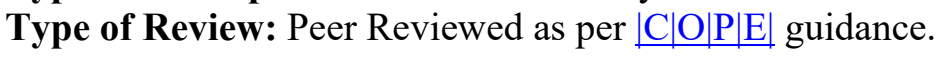

Indexed In: OpenAIRE.

DOI: http://doi.org/10.5281/zenodo.4108162

Google Scholar Citation: IJCSBE.

\section{How to Cite this Paper:}

Anjay Kumar Mishra, Aithal, P. S. and Hamid Saremi (2020). Financial Mobilization Status of People Housing Program; A case of Rupandehi District of Nepal. International Journal of Case Studies in Business, IT, and Education (IJCSBE), 4(2), 193-202. DOI: http://doi.org/10.5281/zenodo.4108162

International Journal of Case Studies in Business, IT and Education (IJCSBE) A Refereed International Journal of Srinivas University, India.

(C) With Authors.

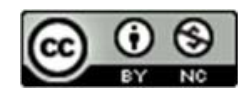

This work is licensed under a Creative Commons Attribution Non-Commercial 4.0 International License subject to proper citation to the publication source of the work.

Disclaimer: The scholarly papers as reviewed and published by the Srinivas Publications (S.P.), India are the views and opinions of their respective authors and are not the views or opinions of the S.P. The S.P. disclaims of any harm or loss caused due to the published content to any party. 


\title{
Financial Mobilization Status of People Housing Program - A Case of Rupandehi District of Nepal
}

\author{
Anjay Kumar Mishra*, P. S. Aithal** \& Hamid Saremi*** \\ *Associate Professor, Madan Bhandari Memorial Academy Nepal, Urlabari 3, Morang, Nepal \\ OrcidID: 0000-0003-2803-4918; Email: anjaymishra2000@gmail.com \\ **Professor, College of Management \& Commerce, Srinivas University, Mangalore, India \\ OrcidID: 0000-0002-4691-8736; E-mail: psaithal@gmail.com \\ ***Professor, Industrial Engineering Department, Asar Higher Institute of Education, Masahad- \\ Iran, Email; hadi_sarem@yahoo.com
}

\begin{abstract}
The overall objective of this study is to assess the implementation status of Janata Awash Program in Rupandehi, Nepal, where the program is scattered over 13 VDC and 4 Municipality (before readjustment of local level). Up to last fiscal year around 430 houses are completed through Janata Awash Program phase I and 18 houses are added in the second phase and remain 52 houses are canceled due to different reasons. In phase II 13 houses are canceled and 125 are on the implementation phase and near to compete. Earned value analysis has been carried out based on physical progress and financial progress which shows that the program is behind the planned schedule and under budget.
\end{abstract}

Keywords: Implementation, Phase I, Phase II, Earn Value Analysis

\section{INTRODUCTION :}

Housing is one of the basic needs for all the people and the inclusion must be focussed in the process of providing the housing facilities to the people. The Government of Nepal has implemented a special housing program called 'People Housing Program' (Janata Awash Karyakram) targeted especially for the dalits (untouchables) deprived and backward groups like Chepang, Bankariya and deprived class of TeraiMadhesh (Southern Plain). The program was started in the Fiscal Year 2009/2010 and has adopted the policy of implementing this program also for the Raute, Kusunda as well as the badi communities. The program is focused on the deprived class and marginalized ethnic groups of the society. And also, the government of Nepal has the aim to construct 22647 units of houses in the whole country last year (DUDBC, 2019) [1]. These houses are constructing under the supervision of the division office. This program is now widely spread in 74 districts of Nepal. Janta Awash in Rupandehi has a widespread work area than other districts. It covers 13 village development committees and four municipalities. So, during the beneficiaries' selection and formation of the user committee before construction may create different problems and challenges also on the construction stage. Due to this problem, construction speed and progress are directly affected. And also, the people thought about the program are different from the goal of government. The present condition of the housing implementation project has also not been studied yet. Hence, it is necessary to obtain implementation challenges for the low-income group of people in the Rupandehi district in a proper way.

\section{OBJECTIVES :}

To find out the financial mobilization status and work progress for the housing under construction to the targeted group of the low-income people in Rupandehi of Nepal.

\section{DATA COLLECTION :}

The secondary data have been obtained from DUDBC office, I/NGO'S along with a discussion of key persons.

\section{ANALYTICAL RESEARCH}

The analytical research was helpful to carry Earned value analysis for finding out the relation between 
financial progress and physical progress. Data obtained from the Ministry of Physical Infrastructure Development Province No. 5 was used for this analysis by using the following formulas (MOPID, 2019) [2].

Planned Value (PV)

Earned value $(\mathrm{EV})=$ value of the $\%$ of work complete

Actual cost (AC)

BAC

Cost variance $(\mathrm{CV})=\mathrm{EV}-\mathrm{AC}$

Schedule Variance $(\mathrm{SV})=\mathrm{EV}-\mathrm{PV}$

Cost Performance Index $(\mathrm{CPI})=\mathrm{EV} / \mathrm{AC}$

Schedule Performance Index $(\mathrm{SPI})=\mathrm{EV} / \mathrm{PV}=$

If there is no variance at all:

Estimate at Completion $(\mathrm{EAC})=\mathrm{BAC}$

Estimate to Compete $(\mathrm{ETC})=\mathrm{EAC}-\mathrm{AC}$

If there is no variance and it is expected to continue:

Estimate at Completion $(\mathrm{EAC})=\mathrm{BAC} / \mathrm{CPI}$

Estimate to Compete $(\mathrm{ETC})=(\mathrm{BAC} / \mathrm{CPI})-\mathrm{AC}$

If there is variance, but now it's gone:

Estimate at completion $(\mathrm{EAC})=\mathrm{AC}+\mathrm{BAC}-\mathrm{EV}$

Estimate to Compete $(\mathrm{ETC})=\mathrm{BAC}-\mathrm{EV}$

Variance at Completion $(\mathrm{VAC})=\mathrm{BAC}-\mathrm{EAC}$

(i). If there is no variance at all:

$\mathrm{VAC}=\mathrm{BAC}-\mathrm{EA}$

(ii). If there is no variance and it is expected to continue:

$\mathrm{VAC}=\mathrm{BAC}-\mathrm{EAC}$

(iii). If there is variance, but now it's gone:

$\mathrm{VAC}=\mathrm{BAC}-\mathrm{EAC}$

Total Cost Performance Index $(\mathrm{TCPI})=(\mathrm{BAC}-\mathrm{EV}) /(\mathrm{EAC}-\mathrm{AC})$

(i). If there is no variance at all:

To Complete Performance Index $(\mathrm{TCPI})=(\mathrm{BAC}-\mathrm{EV}) /(\mathrm{EAC}-\mathrm{AC})$

(ii). If there is no variance and it is expected to continue:

To Complete Performance Index $(\mathrm{TCPI})=(\mathrm{BAC}-\mathrm{EV}) /(\mathrm{EAC}-\mathrm{AC})$

(iii). If there is variance, but now it's gone:

To Complete Performance Index $(\mathrm{TCPI})=(\mathrm{BAC}-\mathrm{EV}) /(\mathrm{EAC}-\mathrm{AC})$

Note: $\mathrm{BAC}=$ Budget at Completion

Table 1: Summary of Methodology

\begin{tabular}{|c|c|c|c|}
\hline $\begin{array}{l}\text { Objective; To find out } \\
\text { the financial } \\
\text { mobilization status } \\
\text { and work progress for } \\
\text { the housing under } \\
\text { construction to a } \\
\text { targeted group of the } \\
\text { people in Rupandehi } \\
\text { of Nepal }\end{array}$ & $\begin{array}{l}\text { Data needed; Progress } \\
\text { report and status and } \\
\text { other data basically } \\
\text { DUDBC, } 2011[3] \\
\text { DUDBC, 2019 and } \\
2017 \text { [4] Lumanti 2008 } \\
\text { and 1995 [5-6], MOPID } \\
\text { 2076BC [2] }\end{array}$ & $\begin{array}{l}\text { Collected from; } \\
\text { Government Bodies, } \\
\text { NGOs, INGOs and } \\
\text { constructive adoption of } \\
\text { methods and comparison } \\
\text { from Mishra and Shah } \\
(2018) \text { [7], Shah and } \\
\text { Mishra (2018) [8], Mishra, } \\
\text { (2019) [9] was done } \\
\text { throughout the study. }\end{array}$ & $\begin{array}{lr}\text { Earned } & \text { Value } \\
\text { Analysis } & \text { methods } \\
\text { (adopted } & \text { from } \\
\text { Mishra and Bhandari } \\
2018[10] \text { ). }\end{array}$ \\
\hline
\end{tabular}




\section{RESULTS AND DISCUSSIONS :}

\subsection{WORK PROGRESS AND IMPLEMENTATION STATUS :}

Status of user committee :

Among 500 numbers of total selected applicants, 448 numbers of applicants joined on different construction having committee members ranging from 5 to 18 . In the second phase also among 138 numbers, 124 numbers joined on different user committees as the same process of phase I based on the Implementation Guidelines of Janata Awash Program. Details are shown below in table 2.

Table 2: Working through the Status of Rupandehi

\begin{tabular}{|l|l|l|l|}
\hline Rupandehi Phase I & $\begin{array}{l}\text { Worked through User } \\
\text { Total Houses No. }\end{array}$ & $\begin{array}{l}\text { Worked through single } \\
\text { beneficiaries }\end{array}$ & Canceled \\
\hline 500 & 448 & 4 & 52 \\
\hline
\end{tabular}

Rupandehi Phase II

\begin{tabular}{|l|l|l|l|}
\hline Total Houses No. & $\begin{array}{l}\text { Worked through User } \\
\text { Committee }\end{array}$ & $\begin{array}{l}\text { Worked through single } \\
\text { beneficiaries }\end{array}$ & canceled \\
\hline 138 & 124 & 11 & 13 \\
\hline
\end{tabular}

(Source: UDBO, Rupandehi)

Cause of cancelations and the details of the progress of single applicants are documented and presented in table 11. There are around 58 numbers of user committee expressed their view the process of implementation of through user committee is very much effective and they felt very easy to work on group.

Tribe (Jati) Wise Selected Detail of Applicants in Phase I.

The details of Jati wise distribution of applicants in phase I of the program based on the distribution area are presented below in table 3 .

Table 3: Total Applicants Status of Janata Awash Karyakram in Rupandehi

\begin{tabular}{|l|l|l|l|l|l|}
\hline SN & Location & $\begin{array}{l}\text { Total } \\
\text { Applicants No's }\end{array}$ & $\begin{array}{l}\text { Selected } \\
\text { Applicants No's }\end{array}$ & $\begin{array}{l}\text { Hindu } \\
\text { Selected } \\
\text { Applicants }\end{array}$ & $\begin{array}{l}\text { Musalmans } \\
\text { Selected } \\
\text { Applicants }\end{array}$ \\
\hline 1 & DEVDAHA & 281 & 60 & 57 & 3 \\
\hline 2 & TILIOTTAMA & 165 & 29 & 28 & 1 \\
\hline 3 & SAINAMANA & 184 & 43 & 43 & 0 \\
\hline 4 & LUMBINI & 338 & 85 & 50 & 35 \\
\hline 5 & BODHABAR & 261 & 63 & 55 & 8 \\
\hline 6 & DHAKADHAI & 78 & 17 & 12 & 5 \\
\hline 7 & POKHARBHINDI & 32 & 5 & 2 & 3 \\
\hline 8 & SIKTAHAN & 144 & 36 & 32 & 4 \\
\hline 9 & BAGAHA & 62 & 11 & 7 & 4 \\
\hline 10 & BSANTAPUR & 32 & 8 & 6 & 2 \\
\hline 11 & MAINAHIYA & 66 & 13 & 11 & 2 \\
\hline 12 & HATIBANGAI & 56 & 7 & 7 & 0 \\
\hline 13 & BISNUPURA & 80 & 22 & 16 & 6 \\
\hline
\end{tabular}

Anjay Kumar Mishra, et al. (2020); www.srinivaspublication.com 
International Journal of Case Studies in Business, IT, and Education (IJCSBE), ISSN: 2581-6942, Vol. 4, No. 2, October 2020

\begin{tabular}{|l|l|l|l|l|l|}
\hline 14 & SURYAPURA & 91 & 22 & 19 & 3 \\
\hline 15 & BOGADI & 82 & 20 & 20 & 0 \\
\hline 16 & RAYAPUR & 68 & 19 & 17 & 2 \\
\hline 17 & KARAUTA & 194 & 40 & 23 & 17 \\
\hline & Total & 2214 & 500 & 405 & 95 \\
\hline
\end{tabular}

(Source: UDBO, Rupandehi)

Area Wise Implementation Status of Phase I :

Area wise implementation status and progress report of Janata Awash Program of phase (I) are shown in Table 4.430 numbers of houses are completely constructed and handover to the related households, 3 numbers of houses are under construction and the rest of 500 are canceled. Among canceled houses, 18 number of houses are selected and again started to construct through the second phase and still on the implementation phase.

Table 4 : Area Wise Implementation Status and Progress Report of Phase I

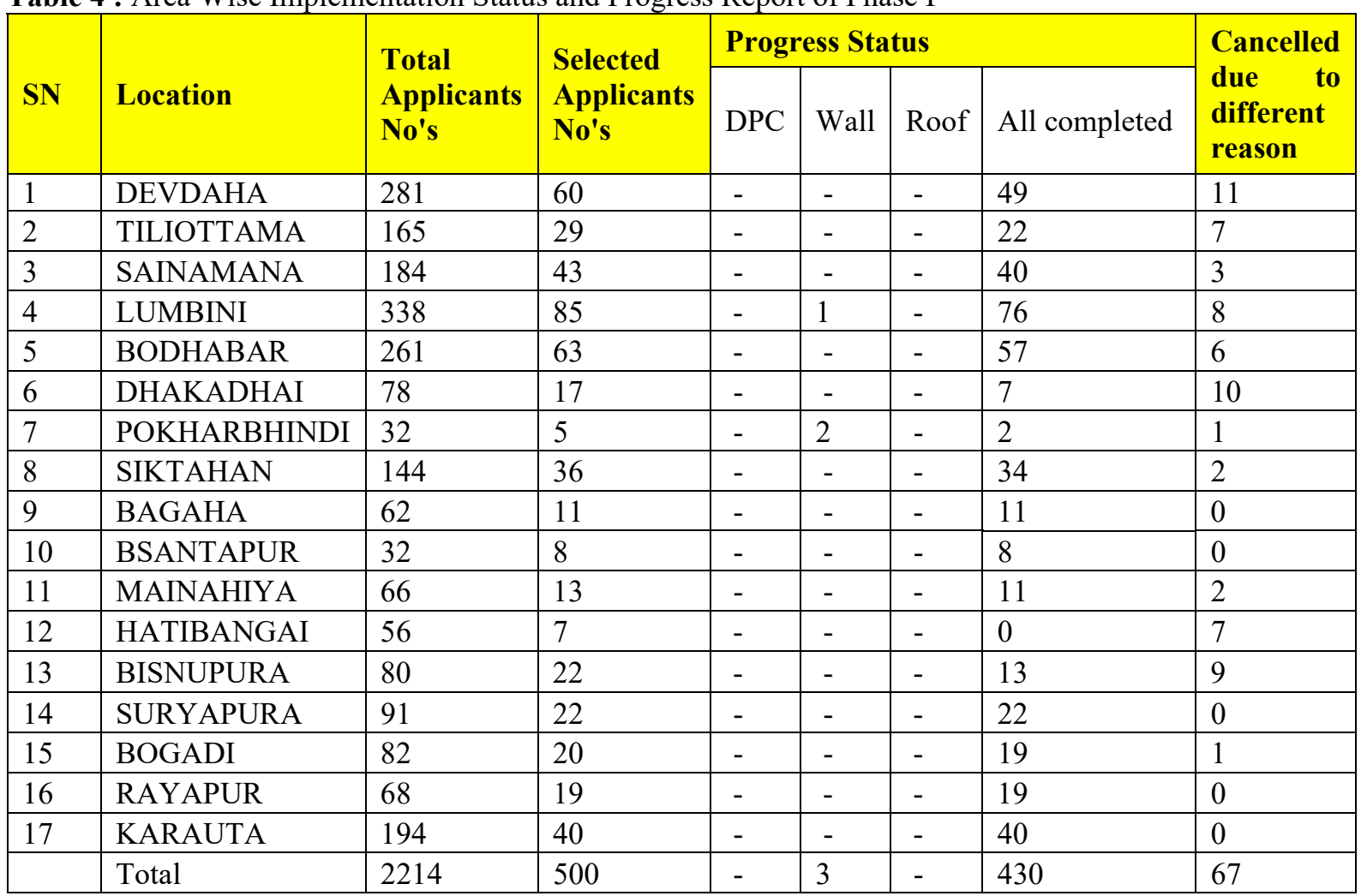

(Source: UDBO Rupandehi)

\section{Election Area wise Selected Applicants distribution in Phase II :}

During the panning of the second phase, the program is planned to distribute in all election area and a total no of houses to be constructed on different election areas were decided first as shown below in table 5. This table also shows the number of hindus and musalmans selected numbers of household.

Table 5 : Selected Applicants Distribution in Phase II

\begin{tabular}{|l|l|l|l|l|}
\hline SN & Election Area No & Hindu & Musalmans & Total \\
\hline 1 & $1 k a$ & 8 & 2 & 10 \\
\hline 2 & $1 k h a$ & 6 & 4 & 10 \\
\hline
\end{tabular}




\begin{tabular}{|l|l|l|l|l|}
\hline 3 & $2 k a$ & 10 & 0 & 10 \\
\hline 4 & $2 k h a$ & 0 & 0 & 0 \\
\hline 5 & $3 k a$ & 0 & 0 & 0 \\
\hline 6 & $3 k h a$ & 6 & 2 & 8 \\
\hline 7 & $4 k a$ & 14 & 6 & 20 \\
\hline 8 & $4 k h a$ & 20 & 0 & 20 \\
\hline 9 & $5 k a$ & 28 & 2 & 30 \\
\hline 10 & $5 k h a$ & 18 & 12 & 30 \\
\hline & Total & 110 & 28 & 138 \\
\hline
\end{tabular}

(Source: UDBO Rupandehi)

Election region number wise Implementation Status and Progress Report of Phase II :

In the second phase among 138 selected numbers of beneficiaries, 13 numbers of houses are canceled, one house is on DPC complete phase, another is also on wall complete phase, 76 numbers of houses are on the phase of roof completion, finally, 53 numbers of houses are on the phase of toilet completion and finally three number of houses are ready to hand over until last of the fiscal year 2015/16. Details of elections wise progress status are shown below in table 6 .

Table 6 : Election no Wise Implementation Status and Progress Report of Phase II

\begin{tabular}{|l|l|l|l|l|l|l|l|l|}
\hline S.N. & $\begin{array}{l}\text { Election } \\
\text { Region } \\
\text { No. }\end{array}$ & $\begin{array}{l}\text { Total } \\
\text { Houses }\end{array}$ & $\begin{array}{l}\text { DPC } \\
\text { completed }\end{array}$ & $\begin{array}{l}\text { Wall } \\
\text { completed }\end{array}$ & $\begin{array}{l}\text { Roof } \\
\text { Completed }\end{array}$ & $\begin{array}{l}\text { Toilet } \\
\text { completed }\end{array}$ & $\begin{array}{l}\text { All } \\
\text { completed }\end{array}$ & $\begin{array}{l}\text { No. of } \\
\text { Not } \\
\text { started } \\
\text { houses }\end{array}$ \\
\hline 1 & $1(1)$ & 10 & 1 & - & 1 & 4 & 3 & 1 \\
\hline 2 & $1(2)$ & 10 & - & - & 1 & 6 & - & 3 \\
\hline 3 & $2(2)$ & 10 & - & - & 1 & 5 & - & 4 \\
\hline 4 & $3(2)$ & 8 & - & - & 4 & 4 & - & - \\
\hline 5 & $4(1)$ & 20 & - & - & 12 & 8 & - & - \\
\hline 6 & $4(2)$ & 20 & - & - & 10 & 10 & - & - \\
\hline 7 & $5(1)$ & 30 & - & 1 & 19 & 6 & - & 4 \\
\hline 8 & $5(2)$ & 30 & - & - & 19 & 10 & - & 1 \\
\hline & Total & 138 & 1 & 1 & 67 & 53 & 3 & 13 \\
\hline
\end{tabular}

(Source: UDBO Rupandehi)

\section{Work Progress and Implementation status of UDBO Rupandehi :}

The total implementation status and progress of Rupandehi, Kpilbastu, Argakhanchi, Palpa, Nawalparasi (Susta-West) up to Fiscal year 2015/16 implemented through UDBO Rupandehi is shown in table 7.

Table 7: Total Work Progress and Implementation Status of UDBO Rupandehi

\begin{tabular}{|l|l|}
\hline Building Office Rupandehi \\
\hline Progress Level & No of Housing Units \\
\hline Plinth level completed & 18 \\
\hline Wall Level completed & 14 \\
\hline Roof work Complete & 76 \\
\hline Toilet work Remained & 405 \\
\hline All Completed & 1134 \\
\hline
\end{tabular}

(Source: UDBO Rupandehi) 
As per the data of Fiscal Year, 2018/019 obtained from the Ministry of Physical Planning and Infrastructure Development province No 5, financial progress and physical progress and budget details are shown below in table 8 .

Table 8: Financial Status of Janata Awash Program in Rupandehi

\begin{tabular}{|l|l|l|l|l|}
\hline Program Name & $\begin{array}{l}\text { Allocated } \\
\text { Budget }\end{array}$ & $\begin{array}{l}\text { Spent } \\
\text { Budget }\end{array}$ & $\begin{array}{l}\text { Financial } \\
\text { Progress }\end{array}$ & $\begin{array}{l}\text { Physical } \\
\text { Progress }\end{array}$ \\
\hline Janata Awash Program & $\begin{array}{l}\text { Rs } \\
74774000\end{array}$ & $\begin{array}{l}\text { Rs } \\
45877800\end{array}$ & $61.63 \%$ & $75 \%$ \\
\hline
\end{tabular}

(Source: MOPID Province No 5)

Table 9: Financial Mobilization and Payment Stage of Janata Awash Program

\begin{tabular}{|l|l|l|}
\hline \multicolumn{2}{|l|}{ I phase 2016/017 Program } & II phase 2018/019 Program \\
\hline $\begin{array}{l}\text { Financial Mobilization } \\
\text { Stage }\end{array}$ & Amount in Rs & Amount in Rs \\
\hline First Installment & 53810 & 83125 \\
\hline Second Installment & 64570 & 99750 \\
\hline Third Installment & 75330 & 116375 \\
\hline Final Installment & 21529 & 33250 \\
\hline Contingencies & 10761 & 17500 \\
\hline Total & 226000 & 350000 \\
\hline
\end{tabular}

Table 9 clearly showed the installment details of the program during the implementation stage of both phases I and II. The first installment is provided to beneficiaries after the work completion of the plinth level and simultaneously other installments are provided after the completion of wall erection roof completion and finally successfully construction of the toilet and set up windows and door.

\section{Financial Status Based on Election Area :}

Payment for a new agreement, Payment for old agreement, total allocated budget in F/Y 2018/019and remaining in allocated budget details based on different election areas are shown clearly below on table 10 .

Table 10: Election Area Wise Amount Spent to Users in Phase II of Rupandehi

\begin{tabular}{|c|c|c|c|c|c|}
\hline S.N. & $\begin{array}{l}\text { Election } \\
\text { Region } \\
\text { No. } \\
\end{array}$ & $\begin{array}{l}\text { Payment for new } \\
\text { agreement }\end{array}$ & $\begin{array}{l}\text { Payment for old } \\
\text { agreement }\end{array}$ & $\begin{array}{l}\text { Total Allocated } \\
\text { Budget in } \\
\text { F/Y2075-76 }\end{array}$ & $\begin{array}{l}\text { Remaining in } \\
\text { Allocated } \\
\text { Budget }\end{array}$ \\
\hline 1 & $1(1)$ & 5449085 & 1320183 & \multirow{10}{*}{45315696.00} & 736345 \\
\hline 2 & $1(2)$ & 2034900 & 235369 & & 232750 \\
\hline 3 & $2(2)$ & 1879225 & 395211 & & 199500 \\
\hline 4 & $3(1)$ & 1197000 & 41980 & & 133000 \\
\hline 4 & $3(2)$ & 2394000 & 82200 & & 232750 \\
\hline 5 & $4(1)$ & 5985000 & - & & 665000 \\
\hline 6 & $4(2)$ & 5985000 & - & & 665000 \\
\hline 7 & $5(1)$ & 8079750 & 164540 & & 897750 \\
\hline \multirow[t]{2}{*}{8} & $5(2)$ & 9875250 & 197003 & & 1097250 \\
\hline & Total & 42879210.00 & 2436486.00 & & 4859345.00 \\
\hline
\end{tabular}

(Source: UDBO Rupandehi as of DUDBC, 2019) 


\subsection{Earned Value Analysis of Program :}

As per data from the Ministry of Physical Infrastructure Development (2019) and methods adopted from Mishra and Bhandari (2018), the allocated budget and Spent budget for F/Y 2018/19 was Rs. 74774000 and Rs. 45877800 respectively. Also, the physical progress was found as $75 \%$ where financial progress as $61.63 \%$.

In this program (PHP), Schedule variance was found as Rs -18693500; it means the program is behind the schedule, Cost variance was found as Rs 10202700; it means the program is under budget.

Here, the value of CPI is 1.223 , i.e. Higher than 1 , then it indicates the project is under budget.

Here, the value of SPI is 0.75 i.e. less than schedule it indicates the project is performing only $75 \%$ of work on schedule.

If there is no variance at all: the value of EAC (Estimate at completion) was found as Rs 74774000; it means Rs 74774000 is the estimated amount for completion of work, the value of ETC (Estimate to complete) was found as Rs 28896200; it means Rs 28896200 will be required for the completion of remaining work, here in this case, no variation is considered so VAC is zero, the value of TCPI (To complete performance index) was found as 0.64691 ; it means we can continue with a cost performance index of 0.64691 to complete the project.

If there is variance and it is expected to continue: the value of EAC (Estimate at completion) was found as Rs 61170400; it means Rs 61170400 is the estimated amount for completion of work, the value of ETC (Estimate to complete) was found as Rs1529260; it means Rs 1529260 will be required for the completion of remaining work, the value of VAC(variance at completion) is Rs 1360360; it means the project will be under budget by Rs 1360360, the value of TCPI (To complete performance index) was found as 1.22; it means that for the remainder of the project, for each budget rupees spent there must be a gain of Rs 1.22 of earned value.

If there is variance, but now it's gone: the value of EAC (Estimate at completion) was found as Rs 6457130; it means Rs 6457130 is estimated amount for completion of work, the value of ETC (Estimate to complete) was found as Rs1869350; it means Rs 1869350 will be required for the completion of remaining work, the value of VAC(variance at completion) is Rs 1020270; it means the project will be under budget by Rs 1020270, the value of TCPI (To complete performance index) was found as 1 ; it means that the project has just enough funds to complete the work. Other details calculation and their values EAC, ETC, and TCPI based on three various cases of variation are calculated in table 11.

Table 11: Earned Value Analysis

\begin{tabular}{|l|l|}
\hline AS per data from Ministry of Physical Infrastructure Development & Value \\
\hline Allocated Budget $=$ & $7,47,74,000$ \\
\hline Spent Budget $=$ & $4,58,77,800$ \\
\hline Physical Progress $=$ & $75 \%$ \\
\hline Financial Progress $=$ & $61.63 \%$ \\
\hline Project Duration $=$ & $12 \mathrm{Months}$ \\
\hline Planned Value $(\mathrm{PV})=$ & $7,47,74,000$ \\
\hline Earned value $(\mathrm{EV})=$ value of the \% of work complete $=$ & $5,60,80,500$ \\
\hline Actual cost $(\mathrm{AC})=$ & $4,58,77,800$ \\
\hline Budget at completion $(\mathrm{BAC})=$ & $7,47,74,000$ \\
\hline Cost variance $(\mathrm{CV})=\mathrm{EV}-\mathrm{AC}=$ & $1,02,02,700$ \\
\hline Schedule Variance $(\mathrm{SV})=\mathrm{EV}-\mathrm{PV}=$ & $-1,86,93,500$ \\
\hline Cost Performance Index $(\mathrm{CPI})=\mathrm{EV} / \mathrm{AC}=$ & 1.222389 \\
\hline Schedule Performance $\mathrm{Index}(\mathrm{SPI})=\mathrm{EV} / \mathrm{PV}=$ & 0.75 \\
\hline If there is no variance at all: & \\
\hline Estimate at Completion $(\mathrm{EAC})=\mathrm{BAC}=$ & $7,47,74,000$ \\
\hline Estimate to Compete $(\mathrm{ETC})=\mathrm{EAC}-\mathrm{AC}=$ & $2,88,96,200$ \\
\hline If there is variance and it is expected to continue: & \\
\hline Estimate at Completion $(\mathrm{EAC})=\mathrm{BAC} / \mathrm{CPI}=$ & $6,11,70,400$ \\
\hline Estimate to Compete $(\mathrm{ETC})=(\mathrm{BAC} / \mathrm{CPI})-\mathrm{AC}=$ & $1,52,92,600$ \\
\hline
\end{tabular}




\begin{tabular}{|c|c|}
\hline If there is variance, but now it's gone: & \\
\hline Estimate at completion $(\mathrm{EAC})=\mathrm{AC}+\mathrm{BAC}-\mathrm{EV}=$ & $6,45,71,300$ \\
\hline Estimate to Compete $(\mathrm{ETC})=\mathrm{BAC}-\mathrm{EV}=$ & $1,86,93,500$ \\
\hline Variance at completion $(\mathrm{VAC})=\mathrm{BAC}-\mathrm{EAC}$ & - \\
\hline (i). If there is no variance at all: & \\
\hline $\mathrm{VAC}=\mathrm{BAC}-\mathrm{EAC}=$ & 0 \\
\hline (ii). If there is variance and it is expected to continue: & \\
\hline $\mathrm{VAC}=\mathrm{BAC}-\mathrm{EAC}=$ & $1,36,03,600$ \\
\hline (iii). If there is variance, but now it's gone: & \\
\hline $\mathrm{VAC}=\mathrm{BAC}-\mathrm{EAC}=$ & $1,02,02,700$ \\
\hline Total Cost Performance Index $(\mathrm{TCPI})=(\mathrm{BAC}-\mathrm{EV}) /(\mathrm{EAC}-\mathrm{AC})$ & - \\
\hline (i). If there is no variance at all: & \\
\hline To Complete Performance Index $(\mathrm{TCPI})=(\mathrm{BAC}-\mathrm{EV}) /(\mathrm{EAC}-\mathrm{AC})=$ & 0.646919 \\
\hline (ii). If there is variance and it is expected to continue: & \\
\hline To Complete Performance Index $(\mathrm{TCPI})=(\mathrm{BAC}-\mathrm{EV}) /(\mathrm{EAC}-\mathrm{AC})=$ & 1.222389 \\
\hline (iii). If there is variance, but now it's gone: & \\
\hline To Complete Performance Index $(\mathrm{TCPI})=(\mathrm{BAC}-\mathrm{EV}) /(\mathrm{EAC}-\mathrm{AC})=$ & 1 \\
\hline Note: All amounts are in Rs. & \\
\hline
\end{tabular}

\section{CONCLUSION:}

(1) After the study, we found the construction user committee plays a vital role in the successful implementation of the program. 448 and 124 no of beneficiaries are under different construction committees and among them 430 houses already constructed up to last fiscal year. Rests of them are on the implementation phase except for 34 and 13 nos of houses. Whereas four users in I phase and 13 users in II phase are constructing their houses separately.

(2) People really happy from the program and they want to say thanks to the government but expressed their view about house size if slightly large with separate kitchen (especially in musalmans) will be far better.

(3) After the study, it has also shown that the physical progress is greater than financial progress but earned value analysis shows that the program is behind the planned schedule.

\section{RECOMMENDATIONS :}

(1) In tasks assigned to the users' committee, because of incapability or inefficiency of a single member, programs are turning ineffective, so management should be improvised and strengthened.

(2) As per our study on earn value analysis, the delay is significant and behind the schedule. With physical and financial progress at stake and time management in consideration, with sufficient resource allocation, resource management, enhancing technical expertise, boosting awareness among locales, organizing effective mason training sessions, this delay can be substantially reduced.

\section{REFERENCES :}

[1] DUDBC, R. D. (2019). Progress Report 2075/076. Rupandehi,Nepal: DUDBC, Rupandehi Division.

[2] MOPID.P5. (2019). Progress Report F/Y 2075/076. Butwal,Rupandehi: Minstry of Physical Infrastructure Deelopment, Province 5.

[3] DUDBC, (2011). Progress Report 2011. Kathmandu,Nepal: DUDBC. https://www.dudbc.gov.np/division/view/35

[4] DUDBC, R. (2017). Progerss Report of Janata awash karyakram. Bhairahawa: DUDBC,Rupandehi Division.https://www.dudbc.gov.np/division/view/35

[5] LUMANTI, (1995). New Beginning: Housing the Urban Poor. Kathmandu, Nepa: Lumanti Support Group for Shelter.

[6] LUMANTI, (2008). Status on Povery Income, Employment and Urban Facilities in Kathmandu Metropolitan City. Kathmandu: LUMANTI Government of Nepal. 
[7] Mishra A. K. \& Shah S.K. (2018). Estimating Housing Unit for Low Income Group of People in Kathmandu, Nepal. NOLEGEIN Journal of Operations Research \& Management, 1(2), 16-27.

[8] Shah, S. K., \& Mishra, A. K. (2018). Review on Global Practice of Housing Demand Fulfilment for Low Income Group People. NOLEGEIN Journal of Business Ethics, Ethos \& CSR, 1(2), 5-16.

[9] Mishra A. K. (2019). HOUSING NEEDS FULFILMENT FOR LOW-INCOME GROUP. LivaS: International Journal on Livable Space, 04(2), 40-47. DOI: http://dx.doi.org/10.25105/livas.v4i2.

[10] Mishra A. K., Bhandari S. (2018). Performance Assessment of ongoing Construction projects under Town Development Fund, Nepal. Int J Adv Res Civil Stru Engr, 1(1\&2), 27-39.

$* * * * * * * * *$ 